Endon Zh. Garmaev' , Anatoly I. Kulikov'², Bair Z. Tsydypov' ${ }^{1 *}$, Bator V. Sodnomov' ${ }^{1}$, Alexander A. Ayurzhanaev ${ }^{1}$

1 Baikal Institute of Nature Management SB RAS, Ulan-Ude, Russia

${ }^{2}$ Institute of General and Experimental Biology SB RAS, Ulan-Ude, Russia

* Corresponding author: bz61@binm.ru

\title{
đ̃ ENVIRONMENTAL CONDITIONS OF ZAKAMENSK TOWN (DZHIDA RIVER BASIN HOTSPOT)
}

\begin{abstract}
Ecological problems of Zakamensk town are associated with sand deposits that were formed as a result of mining activities of former Dzhidinsky tungstenmolybdenum plant. Sands are accumulated in large quantities and they contain dangerous concentrations of heavy metals. Desertification in an urbanized area is manifested locally, but it differs from agricultural desertification by a profound and comprehensive destructive change in the components of the environment. Maps of soils, vegetation, types of lands, as well as ecological zoning maps of Zakamensk were created. The basis for the creation of electronic maps using GIS were stock, archive and own materials, topographic maps and remote sensing data. Urbanized desertification in Zakamensk is caused by chemical contamination of sandy eluvium, the spreading of pollutants by water flows and wind currents. Erosion occurs both in the form of flat flushing and linear erosion. The most intensive is gully erosion. Quantitative parameters of temporal variability of the erosive rainfall potential for the Zakamensk town are received. The quantitative characteristics of loads of pollutants on the territory of the town are determined on the basis of the erosion-deflation models. The calculations showed that 204 tons/ha of contaminated sand annually falls into the settlement area with water-erosion flows ( $\mathrm{Pb}-3.7$ tons, W 4.3 tons). Moreover, active wind activity led to the deposition of more metals ( $\mathrm{Pb}-5.6$ tons, $W-6.5$ tons) in the town.
\end{abstract}

KEY WORDS: erosion, deflation, residual soils, water streams, erosion rainfall potential, relief erosion index

CITATION: Endon Zh. Garmaev, Anatoly I. Kulikov, Bair Z. Tsydypov, Bator V. Sodnomov, Alexander A. Ayurzhanaev (2019) Environmental Conditions Of Zakamensk Town (Dzhida River Basin Hotspot). Geography, Environment, Sustainability,

Vol.12, No 3, p. 224-239

DOI-10.24057/2071-9388-2019-32 


\section{INTRODUCTION}

The use of mineral deposits lies at the heart of our civilization. Mineral extraction is one of the most powerful types of technogenesis. Its impact on the natural environment is increasing and spreading over large areas. In mining regions, huge amounts of waste are generated during the extraction of minerals (Karthe et al., 2014). These are the large areas of almost complete destruction of natural landscapes, occupied by mines, wells, quarries, rock dumps, wastes of primary ore beneficiation (tailings), heaps, transport trunk lines, etc. In recent decades, one of the main problems of environmental safety is the elimination of the consequences of past economic activity.

This paper considers urban ecosystem of Zakamensk, and within its boundaries, the area of activity of the former Dzhidinskky tungsten-molybdenum plant (DTMP). The town is located on the south-west of the Republic of Buryatia near state border with Mongolia in $404 \mathrm{~km}$ from Ulan-Ude in the central part of the Dzhida ridge (Fig. 1). The research subject is located in the mountain-taiga area of the valley of the river Modonkul, the right tributary of the Dzhida river which belongs to the largest Baikal Lake drainage system - the Selenga River (Chalov et al., 2013; Chalov et al., 2015; Karthe et al., 2017; Environmental Atlas-monograph ..., 2019). The height of the mountain valley bottom is about 1100 meters above sea level; the mid-altitude mountains with absolute height of 13001400 meters are adjacent to the town.

The emergence of Zakamensk is inextricably connected with the activity of DTMP, which was established in 1934 by order of the USSR People's Commissariat of Heavy Industry on the basis of the Dzhidinsky ore cluster, which unites Pervomaiskoye molybdenum deposit and Holtoson and Inkur tungsten deposits. In the pre-war and war years, the plant was a leader in tungsten concentrate production. Thus, its production in 1934 was $73.5 \%$, in $193565.7 \%$, in $193750 \%$, in $194440 \%$ of the total volume of tungsten concentrate produced in the USSR (Implementation ..., 2007). In the postwar years, the plant increased its production capacity of tungsten and molybdenum concentrates. In 1992, in connection with the conversion of the military industry, the production decreased by 70 \%. February 26, 1998 Dzhidinsky tungsten-molybdenum plant ceased to exist (Implementation ..., 2007).

During the shutdown of the plant, the sanitary and environmental requirements for the closing enterprises were not met. Mining operations were stopped, but the mine workings were not eliminated (after the plant was shut down, toxic tailings known as "Gidrootval" (Hydro Dump) and "Lezhaliye peski" (Deserted Sands) remained); reclamation of disturbed lands was not carried out; issues of stopping the discharge of polluted mine water into surface water bodies were not resolved;

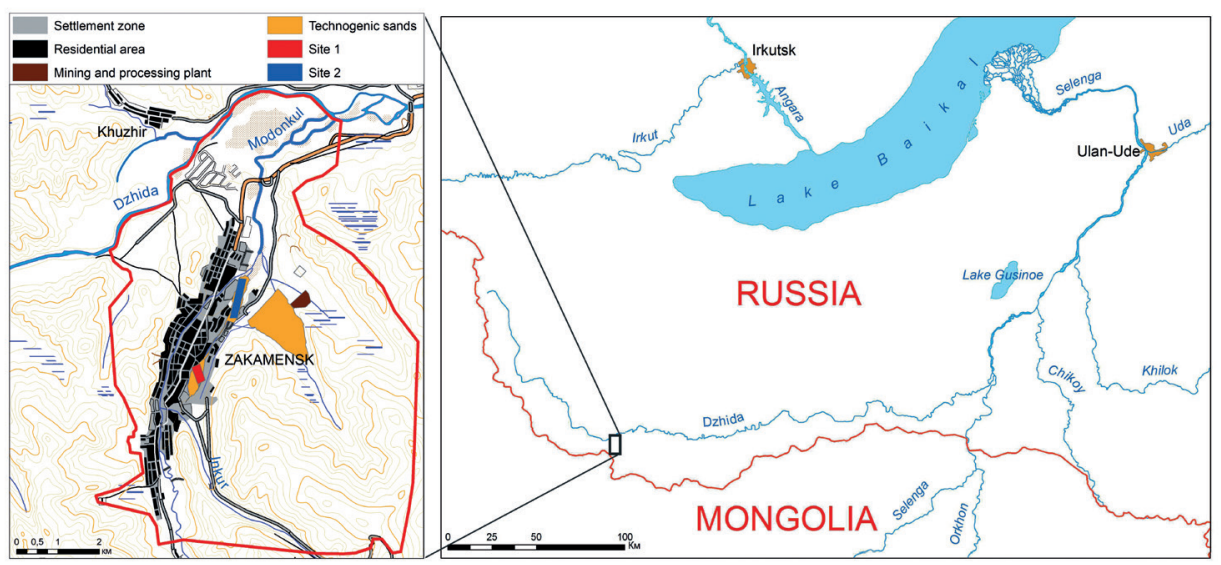

Fig. 1. Geographical location of Zakamensk town 
design environment protection solutions in the area of Zakamensk and adjacent territories were not implemented, etc. All this led to the fact that with the suspension of the plant's activities, the negative impact of its waste on the environment and the population not only did not decrease, but also significantly increased (Timofeev et al., 2018).

During the period of the plant's operation, 44.5 million tons of enrichment waste were stored in tailing dumps.

The goal of the study is a quantitative assessment of the transfer of pollutants (heavy metals) to the territory of Zakamensk from technogenic sands by water and wind flows.

The following tasks were set:

1) to determine the boundaries and geographical location of the polluted territory of Zakamensk;

2) to develop large-scale cartographic models of soils, vegetation, land types and ecological zoning of the town;

3) to identify the quantitative parameters of heavy metal pollution due to watererosion processes, as well as deflation.

\section{MATERIALS AND METHODS}

Ecological problems of Zakamensk are associated with sand deposits (technoeluvium) - the consequences of mining activities. Concentrating plants are located here, and the tailing dump of the former Dzhidinsky tungstenmolybdenum combine adjoins the residential area. Sands are accumulated in large quantities and contain dangerous concentrations of heavy metals. Desertification in an urbanized area (urban desertification) appears locally, and differs from agricultural one by a profound and comprehensive destructive change in the environment components.

In this paper maps of soils, vegetation, types of lands, as well as ecological zoning maps of Zakamensk were created with the help of geoinformation system ArcGIS 10.2. The basis for the creation of electronic maps using GIS were stock, archive and own materials, topographic maps and remote sensing data (Khamnaeva et al., 2013).

In Zakamensk urban desertification is associated with chemical pollution of sandy techno-eluvium and the spreading of pollutants by water and

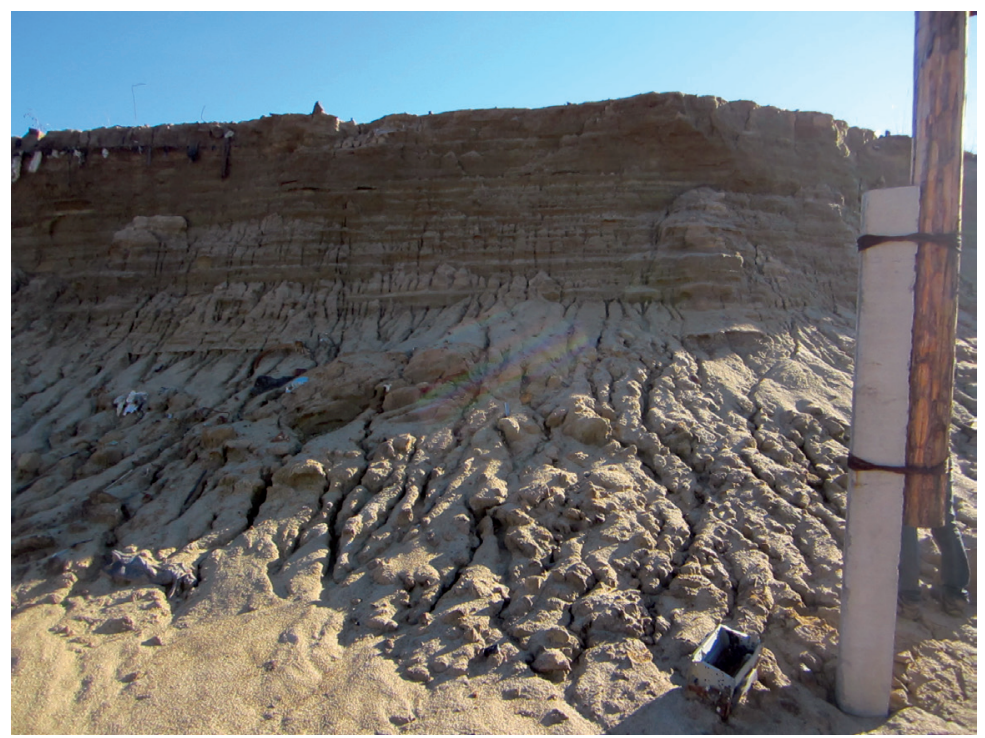

Fig. 2. Sheet erosion of the techno-eluvium surface 


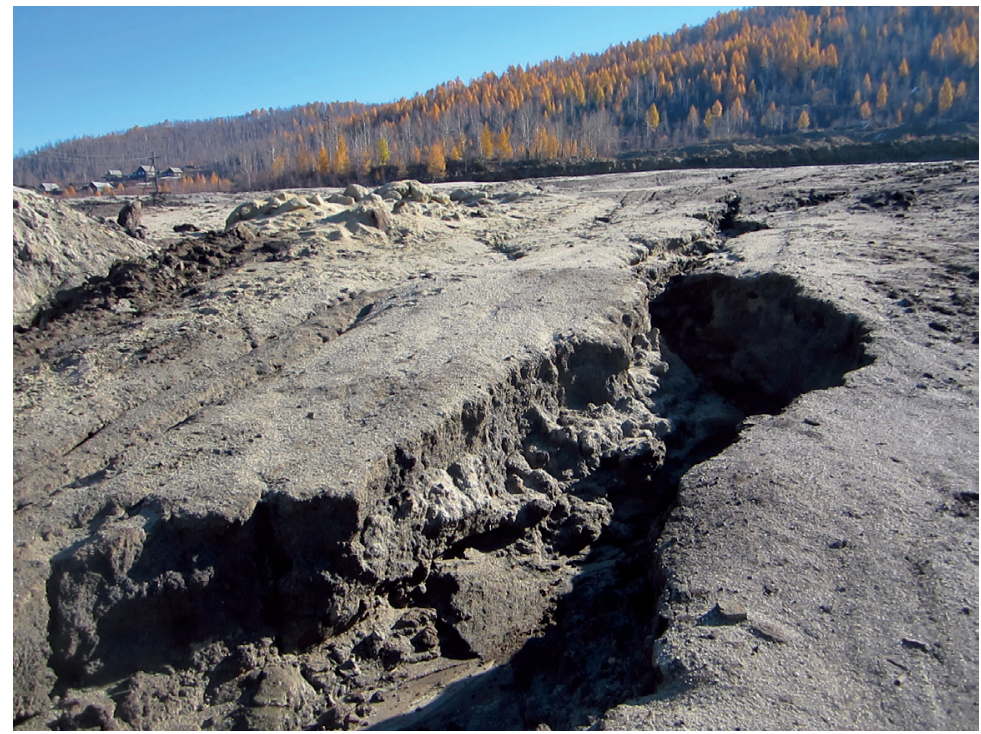

Fig. 3. Gully erosion of the techno-eluvium surface

wind currents (Kulikov et al., 2012; Khamnaeva et al., 2013; Kasimov et al., 2016). Erosion occurs both in the form of sheet (Fig. 2) and linear erosion (Fig. 3). The most impressive is gully erosion (Tulokhonov et al., 2018).

In Russia, up to 7 million hectares of land are affected by gully erosion, the number of gullies is approaching 15 million, the annual increase in the length of the gully network is more than $20,000 \mathrm{~km}$. Over 700 cities in Russia are exposed to gully erosion (Osintseva, 2001; Kovalev, 2009). Moreover, gully formation in urban area cannot be considered obviously dangerous. There is an interdependent system: city - gully-draw network.

Technoeluvium of Zakamensk refers to loose or loosely connected sands (Table 1). The density of sands is considerable, so the total porosity is low, as is the porosity factor. For erosion it is important that the sands are characterized by a large filtration of moisture.

Among the particle-size fractions, particles larger than $0.2 \mathrm{~mm}$ predominate (Table 2). Thin fractions are contained in an amount of about $12 \%$. By origin and soil texture (GOST (State standard) 25100-95), the deposits of technoeluvium belong to the class of technogenic dispersed soils, to the group of disconnected ones, to a subgroup of natural bulk dislocated formations, to the type of production and economic waste, to the type of sand (GOST, 2001). Since the content of fractions is larger than $0.25 \mathrm{~mm}$ and exceeds $50 \%$, then the sands of technoeluvium have an average size. According to this parameter, sands of techno-eluvium are similar to natural aeolian sands (Ivanov, 1971).

Table 1. Some physical properties of the techno-eluvium sands of Zakamensk

\begin{tabular}{|c|c|c|c|c|c|}
\hline Type & $\rho \mathrm{s}, \mathrm{g} / \mathrm{cm}^{3}$ & $\rho \mathrm{d}, \mathrm{g} / \mathrm{cm}^{3}$ & Void content, vol. \% & $\mathrm{K}_{\Phi^{\prime}} \mathrm{cm} /$ day & $e$ \\
\hline Loose sand & 2.5 & 1.67 & 33 & 140 & 0.50 \\
\hline Sand connected & 2.5 & 1.60 & 36 & 120 & 0.56 \\
\hline
\end{tabular}

Note: $\rho_{s}$-density of the solid phase, $\rho_{d}$ - density of the soil, $K_{\Phi}$ - filtration coefficient, $e$-porosity coefficient, i.e. the ratio of the pore volume to the volume of the solid phase, $e=\left(\rho_{s}-\rho_{d}\right) / \rho_{d}$. 
Table 2. The granulometric composition of the techno-eluvium

\begin{tabular}{|c|c|}
\hline Size of fractions, $\mathrm{mm}$ & Content, $\%$ \\
\hline $1-0.5$ & 36.98 \\
\hline $0.5-0.2$ & 39.28 \\
\hline $0.2-0.074$ & 12.06 \\
\hline $0.074-0.044$ & 5.30 \\
\hline$<0.044$ & 6.38 \\
\hline Total: & 100 \\
\hline
\end{tabular}

In general, erosion begins if the condition is met:

$$
r_{\partial}>q
$$

where $r_{\partial}$ is the precipitation rate; $q$ is the water absorption rate by the surface of the techno-eluvium.

The rate of water flow $(Q)$ at different slope sections $(X)$ is determined by the law:

$$
d Q / d x=r_{\partial}-q
$$

so, it depends on the flow loss as it moves down the slope to absorb, and the erosion loss of the soil ( $V$ ) will depend on $w$ - the cross-sectional area of the drain and I the runoff length:

$$
V=\int_{0}^{l} w d l
$$

The shear force of the water flow $\left(F_{c \partial}\right)$ depends on the flow rate $(v)$, the water layer $(h)$, and the ratio of the mass of the particle $(m)$ to its cross-sectional area $(S)$ :

$$
F_{c d}=f\left(F_{c u}, v, h, m / S\right)
$$

The value of $F_{c a}$ increases with increasing $v$ and $h$ and decreasing $\mathrm{m} / \mathrm{S}$. $F_{c u}$ (the adhesion of soil particles)is in function of the particle density $(\rho)$ and the strength of its bond with other particles $F_{C B^{\prime}}$ depends on the content of colloids in the soil and many other factors:

$$
F_{c u}=f\left(\rho, F_{c B}\right)
$$

Erosion occurs under the condition $F_{c a}>$ $F_{c u}$. The rate of the water flow at which the separation of solid particles from the soil surface begins is called the critical velocity of the flow $\left(V_{k p}\right)$. At the same density, the total cross-section of the particles per volume unit increases with decreasing of size. Therefore, the critical flow velocity is lower for soils with smaller microaggregates and particles than on soils with large particles.

For predictive calculation of erosion of Zakamensk technogenic sands we use the Universal Soil Loss Equation (USLE), developed in the USA (Wischmeier and Smith, 1978). The USLE model has been adapted for the territory of north part of Eurasia in a number of works (Larionov, 1993; Kuznetsov and Glazunov, 2004).

The equation has the form

$$
Q=0.224 \cdot R_{30} \cdot K \cdot L S \cdot C \cdot P
$$

where $Q$ - soil loss during erosion, kg/ $\mathrm{m}^{2} /$ year; $R_{30}$ - rainfall erosion index; $K$ - a complex characteristic of soil properties (erodibility or soil washability); LS - relief erosion potential; $C$ - complex characteristics of the soil use; $P$ - complex characteristics of anti-erosion measures. For our case, the last two terms are equated to unity, because technoeluvium is not used in agriculture.

The Universal Soil Loss Equation makes it possible to determine the soil loss from slopes in a wide range of time scales from one erosive event to the entire period of development. Disadvantage: the inability to calculate the amount of accumulation and redeposition of sediments within the slopes. 
Rainfall erosion index is calculated (Wischmeier, 1959):

$$
R_{30}=E \cdot I_{30} / 100
$$

where $I_{30}$ - 30-minute rainfall intensity, $\mathrm{mm} /$ hour; $E$ is the kinetic energy of the drops for $1 \mathrm{~mm}$ of rainfall falling out on $1 \mathrm{~m}^{2}, \mathrm{~kg}_{\mathrm{F}} \cdot \mathrm{m}$.

Energy of rainfall is determined by the formula (Wischmeier and Smith, 1958):

$$
E=1.213+0.8901 \cdot 1 g r_{\partial}
$$

where $r_{\partial}$ - rainfall intensity, $\mathrm{mm} /$ hour.

To determine the layerwise kinetic energy of rain and, in general, the rainfall erosion index is rather difficult. Moreover, approaches and design schemes should be unified for conducting a comparative analysis. The rainfall erosion index $\left(R_{30}\right)$ is based on the multiply of the precipitation layer on a maximum 30-minute intensity:

$$
R_{30}=0.258 \cdot H \cdot I_{30}-0.149
$$

where $\mathrm{H}$ - precipitation depth, $\mathrm{mm}$.

Index $I_{30}$ is determined by the following equation:

$$
I_{30}=0.121 \cdot \exp (0.0529 \cdot H)
$$

Calculations are made separately for each rainfall with $10 \mathrm{~mm}$ layer or more. Rainfalls

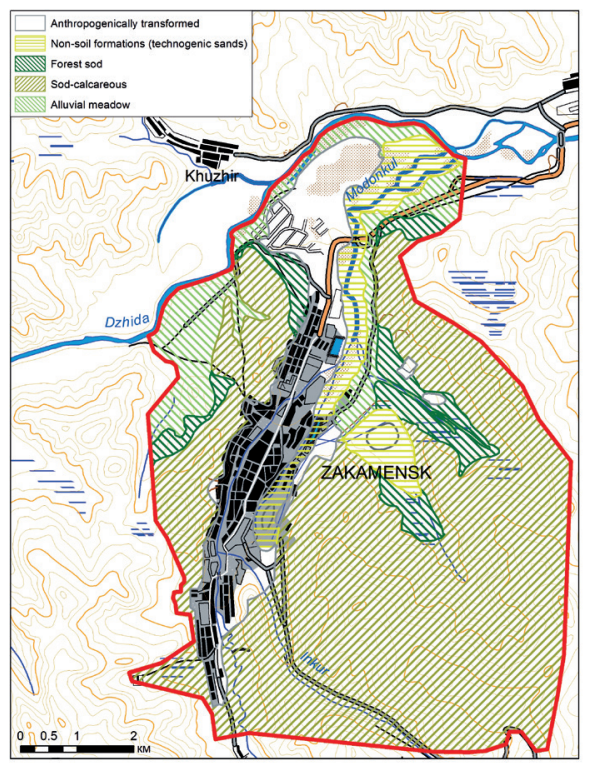

Fig. 4. Soil cover in a smaller amount do not cause a noticeable washout (Tolchelnikov, 1990). Next is the summation of $R_{30}$ individual rainfalls during the season with liquid precipitation.

\section{RESULTS AND DISCUSSION}

\section{Thematic mapping}

Soil is one of the main depositing elements of the ecosystem. According to the soil zoning, the territory of Zakamensk belongs to the Malo-Khamar-Daban mountain district, the East Sayan mountain province of the deciduous forest zone of slightly frozen soils. Sod-forest and floodplain meadow soils dominate. Fig. 4 is a map of the soil cover of the territory of Zakamensk. The following types of soil are identified: 1) sod-calcareous; 2) forest sod; 3) alluvial meadow; 4) anthropogenically transformed; 5) non-soil formations (technogenic sands).

Fig. 5 is a map of the main types of vegetation in Zakamensk, it highlights: 1) valley and floodplain meadows with a combination of shrubs; 2) larch forests with an admixture of birch and aspen: cowberry-forb, forb-gramineous, steppe restoration series in place of light coniferous forests; 3) larch on the

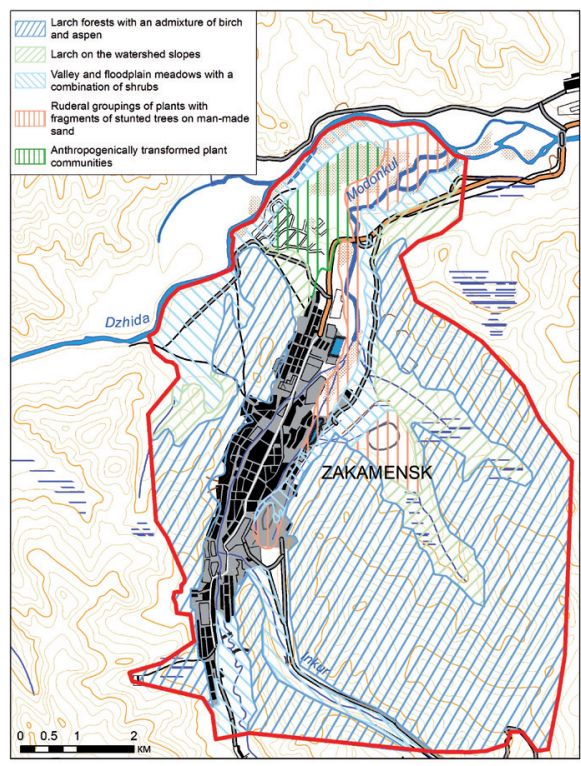

Fig. 5. Vegetation cover 
watershed slopes: grass-lingonberry, 들 grass-moss, shrub; 4) ruderal groupings of plants with fragments of stunted trees on manmade sand; 5) anthropogenically transformed plant communities.

The typology of lands on the town territory is based on their functional purpose. There are 3 groups of land: 1) nature conservation; 2) active economic use; 3) extensive economic use. Among them there are types and subtypes. Types of lands with the intensive use are used to carry out economic activities: processing of natural resources, creating housing, life support systems, transport, communications, etc. There are residential, residential on sands, agricultural, agricultural on overgrown sands, badlands, overgrown badlands and industrial types (Fig. 6). The lands of inconveniences and wastelands (badlands) take a special place, they constitute a reservoir for engaging in economic activity. For Zakamensk these are the areas with technogenic sand. As it can be seen in Fig. 6 , the main structural center of the complex, formed in the lower reaches of the river Modonkul, consists of two spatial formations: residential lands and sandy badlands of tailing dumps, which have the properties of spatial neighborhood and adjunction. The adjunction is caused by the system-forming stream of the channel waters of the river Modonkul. This is especially true of the fluvial flow bed re-deposition of the material of the Kholtoson

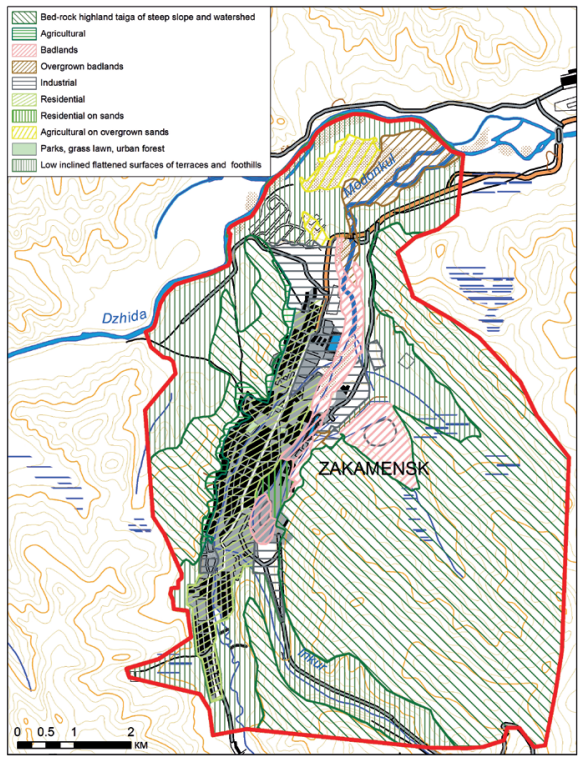

Fig. 6. Types of urban areas deposit and Inkur mining and processing plants. As a result, a plume of sands containing heavy metals in high quantities formed a subparallel residential area.

In addition to creating maps of vegetation, soil cover, and types of urban areas, an ecological zoning map has been created for Zakamensk town (Fig. 7). The boundaries of the zones of ecological status are determined on the basis of a total indicator of soil pollution (Kulikov et al., 2012). The maps of Zakamensk (scales 1:3500 and 1:10000) served as a basis of ecological mapping. The ecological zoning map shows that the territory of Zakamensk is differentiated into areas of ecological disaster and an environmental emergency. The rest of the town belongs to the zone of relatively satisfactory situation. One particular transit area was identified, associated with pollution of bottom silts of the river Modonkul. It is determined by the bottom accumulation coefficient of heavy metals and belongs to the zone of ecological disaster.

\section{EROSION}

In Zakamensk for one rainfall (i) with the layer $\mathrm{H}$ $=14.1 \mathrm{~mm}$ following numbers were obtained: $I_{i 30}=0.121 \cdot \exp (0.0529 \cdot 14.1)=0.121 \cdot \exp (0.718)=$ $0.121 \cdot 2.142=0.259$.

Single rainfall erosion index: $R_{i 30}=$ $0.258 \cdot 14.1 \cdot 0.259-0.149=0.793$.

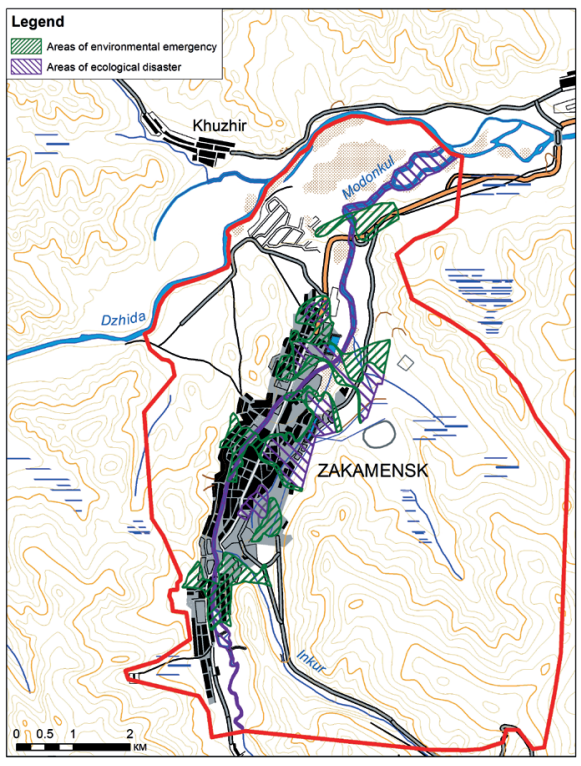

Fig. 7. Zones of ecological disadvantage 
For all rainfalls of one year $S R_{i 30}=8$. To obtain the climatic norm, averaging is usually used for 30 years (in the USA, 22 years). For Zakamensk the average value of $R_{30}$ for 1966-2013 is 21.4 units. According to the sketch map of the rainfall erosion index, Zakamensk area is located between the values of 6 and 10 units (Larionov, 1993).

The distribution of precipitation in the multiyear cycle is affected by global climate change. In Zakamensk changes in erosion rainfall potential (ERP) in 1966-1975 are in the range of 9-37 with an average value of 18.0 units. In the next decade (1976-1985) the fluctuations range expanded to 10-42 with an average value of 16.7 units. In 19861995 there was a further extension of the extremum to 6-111 with an average ERP of 23.6 units. ERP maximum is 111 units was observed in 1992. If we exclude the abnormal year, then we obtain fluctuations in the range 6-28 and an average of 13.9 units. In the next decade (1996-2005) there is a further increase in the average value of ERP to 26 units at extreme values of 3.5-42. In the years 2006-2013 the amplitude of the fluctuations of the ERP continued to increase from 3 to 61 , and the average value reached 25.5 units.
Particularly unstable is the beginning of the 21st century. It follows from the regression equation that the growth of ERP is 2.5 units/10 years (Fig. 8). The general growth of ERP, and especially its instability over the years, indicates that erosion-hazardous rain showers are becoming more likely.

The LS-factor shows how many times the intensity of loss on a given slope with its morphometric characteristics exceeds the loss intensity per unit of precipitation index from the runoff site with the reference length and slope parameters. To calculate the $L S$ relief erosion index, you must have actual values for the steepness and length of the slope. The length of the drainage line of any one type of land is usually taken for the length of the slope from its upper boundary, watershed or artificial drainage boundary (profiled road, ditch, forest belt, etc.) to the lower boundary or thalweg of the ravine (girder), or an artificial drainage boundary. The slope is measured along the steepest part of the slope between two adjacent or several contiguous horizontals.

Erosion contamination sites (Table 3) are located in the eastern part of the city.

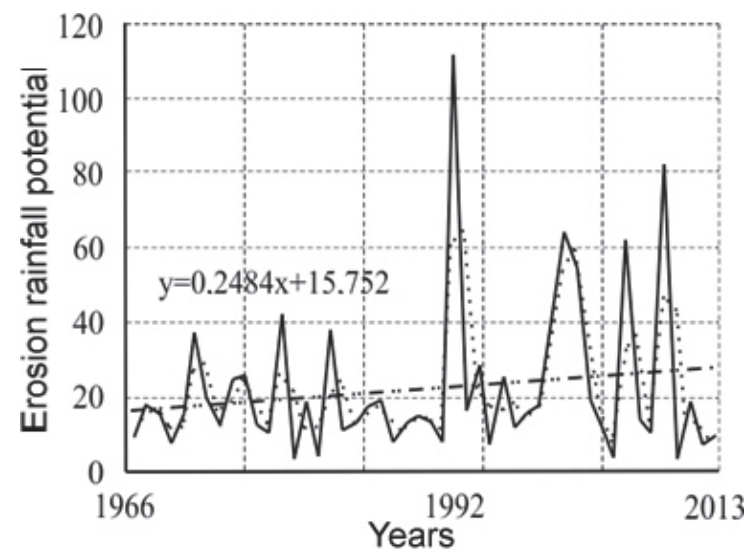

Fig. 8. Long-term dynamics of erosion rainfall potential (R30) from 1966 to 2013 in Zakamensk with a trend, a trend formula and a smoothing curve

Table 3. Morphometric characteristics of the key sites

\begin{tabular}{|c|c|c|c|c|}
\hline Sites & Square, ha & Relative height, $m$ & Drainage line length, $m$ & $\begin{array}{c}\text { Average slope } \\
\text { steepness, }\end{array}$ \\
\hline Site 1 & 30.43 & 37 & 480 & $9.5\left(\operatorname{tg} 9.5^{\circ}=0.167\right)$ \\
\hline Site 2 & 170.4 & 86 & 920 & $21\left(\operatorname{tg} 21^{\circ}=0.384\right)$ \\
\hline
\end{tabular}


The first key site of technoeluvium is an area 으 of 30.43 hectares with the relative height of $37 \mathrm{~m}$, the length of flow line of $480 \mathrm{~m}$, an average steepness of the slope towards the watercourse and an urban area of $9.5^{\circ}$ ( $\mathrm{tg}$ $\left.9.5^{0}=0.167\right)$.

The second site has an area of 170.4 hectares, the height of $86 \mathrm{~m}$, the length of $920 \mathrm{~m}$, an average steepness of the slope towards the drainage stream $21^{\circ}\left(\operatorname{tg} 21^{\circ}=0.384\right)$.

In view of artificial origin and relatively short (on a geological scale) time after dumping, the slopes of sites are even in the longitudinal profile and rugged by erosion ruts, furrows and gullies in the cross direction profile.

$$
L S=L^{0.4} \cdot S^{1.45}
$$

To determine the relief erosion index, we use expression:

For Site 1

LS1 $=480^{0.4} \cdot 0.167^{1.45}=11.817 \cdot 0.075=0.89$.

For Site 2

LS2 $=920^{0.4} \cdot 0.384^{1.45}=15.329 \cdot 0.250=3.83$.

For an approximate rapid determination of $L S$, a nomogram deserves attention (Fig. 9).

From the table values (Kuznetsov and Glazunov, 2004) it follows that the anti-erosion resistance of bare sand technoeluvium can be taken as equal to $K=0.42$.

Taking the received parameters into account, erosion losses of technogenic sands will be on the first site:

$\mathrm{Q}_{1}=0.224 \cdot R \cdot K \cdot L S_{1}=0.224 \cdot 8 \cdot 0.42 \cdot 0.89=0.670 \mathrm{~kg} /$ $\mathrm{m}^{2} /$ year $=6.7 \mathrm{t} / \mathrm{ha} /$ year .

Then, from the entire area of the first site up to 204 tons of contaminated sands fall annually in the city limits.

On the second site:

$\mathrm{Q}_{2}=0.224 \cdot R \cdot K \cdot L S_{2}=0.224 \cdot 8 \cdot 0.42 \cdot 3.83=2.883 \mathrm{~kg} /$ $\mathrm{m}^{2} /$ year $=28.8 \mathrm{t} / \mathrm{ha} /$ year,

so, pressing of pollution on the hydroecosystem of the local water flow is 4907 tons per year.

Soil-erosion pollution of the environment is an independent phenomenon. It is characterized by special soil-erosion migration routes of pollutants in the catchment area. Transport of the substance occurs with slope deposits. Slope deposits undergo hydromechanical selection by fractions and a specific chemical transformation along the slope.

In the area of Lake Baikal the conditional concentration of total phosphorus was $6.0 \mathrm{mg} / \mathrm{l}$ at a soil washout rate of 15.8 tons/ha/year, a loss module of $3.2 \mathrm{t} / \mathrm{ha} / \mathrm{year}$ and an annual water flow layer of $43 \mathrm{~mm}$ (Litvin and Kiryukhina, 2004). The information given by Belotserkovsky M.Yu. and Topunov M.V. (1996) is of a great interest. So, as the latter authors say, in the 90s of the XX century, in Buryatia, with an average plowland area of 1019.2 thousand hectares the average loss was $10.5 \mathrm{t} / \mathrm{ha} /$ year, and the allowable loss was $4.5 \mathrm{t} / \mathrm{ha} /$ year. In general, in the East Siberian region, the intensity of soil erosion from arable land is one of the highest among the economic regions of Russia - 8.1 t/ha/year. In general, in Russia, the washout intensity is $4.3 \mathrm{t} / \mathrm{ha} /$ year. The annual gross erosion from the territory of Eastern

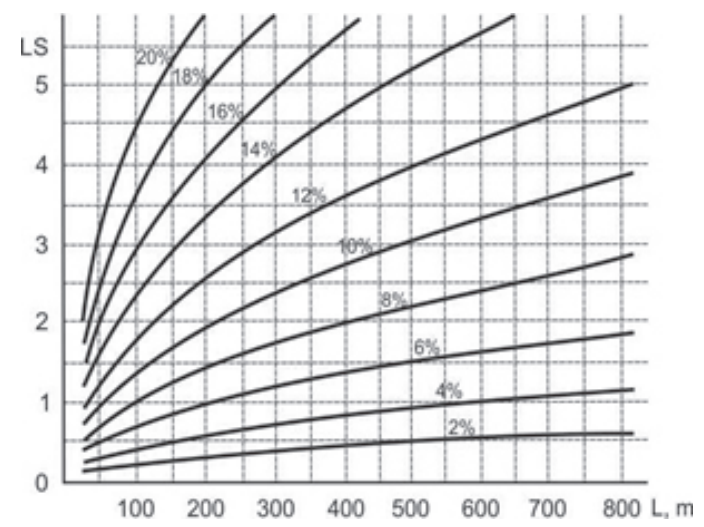

Fig. 9. Nomogram for approximate rapid determination of erosion potential of the relief 
Siberia is 77926.1 thousand tons, and from the territory of Russia - 566240.2 thousand tons.

Khirsanov N.I. and Osipov G.K. (Litvin and Kiryukhina, 2002) developed an empirical formula for the input of phosphorus into the natural environment with products of erosion

$$
W_{p}=0.02 \cdot G^{0.58}
$$

where $G$ - soil erosion module (t/ha), $W_{\text {p }}$ phosphorus output (kg). The exponent in this dependence reflects the relative decrease in the intensity of phosphorus output with increasing soil erosion intensity. Phosphorus is taken as an indicator element.

For technogenic sands of Zakamensk, priority pollutants are $\mathrm{Cd}, \mathrm{Pb}, \mathrm{Zn}, \mathrm{Cu}$, and also $\mathrm{Mo}$ and $\mathrm{W}$

Table 4. Erosion contamination of the territory of Zakamensk by heavy metals

\begin{tabular}{|c|c|c|c|}
\hline $\begin{array}{l}\text { Element - } \\
\text { Pollutant }\end{array}$ & Concentration & Site 1 & Site 2 \\
\hline \multirow{4}{*}{$\mathrm{Cd}$} & a) sands of technogenic eluvium in situ, \% & 0.001 & 0.001 \\
\hline & b) eroded sands, t/t & $1 \cdot 10^{-5}$ & $1 \cdot 10^{-5}$ \\
\hline & c) gross pressing on the urban ecosystem, t/year & $2.04 \cdot 10^{-3}$ & 0.049 \\
\hline & d) pressing for 1996-2011 period, $t$ & 0.030 & 0.700 \\
\hline \multirow{4}{*}{$\mathrm{Pb}$} & a) sands of technogenic eluvium in situ, \% & 0.120 & 0.210 \\
\hline & b) eroded sands, t/t & $1.2 \cdot 10^{-3}$ & $2.1 \cdot 10^{-3}$ \\
\hline & c) gross pressing on the urban ecosystem, t/year & 0.245 & 10.305 \\
\hline & d) pressing for 1996-2011 period, t & 3.700 & 154.600 \\
\hline \multirow{4}{*}{$\mathrm{Zn}$} & a) sands of technogenic eluvium in situ, \% & 0.080 & 0.100 \\
\hline & b) eroded sands, t/t & $8 \cdot 10^{-4}$ & $1 \cdot 10^{-3}$ \\
\hline & c) gross pressing on the urban ecosystem, t/year & 0.163 & 4.907 \\
\hline & d) pressing for $1996-2011$ period, t & 2.400 & 73.600 \\
\hline \multirow{4}{*}{$\mathrm{Cu}$} & a) sands of technogenic eluvium in situ, \% & 0.040 & 0.020 \\
\hline & b) eroded sands, t/t & $4 \cdot 10^{-4}$ & $2 \cdot 10^{-4}$ \\
\hline & c) gross pressing on the urban ecosystem, t/year & 0.082 & 0.981 \\
\hline & d) pressing for 1996-2011 period, t & 12.300 & 14.700 \\
\hline \multirow{4}{*}{ W } & a) sands of technogenic eluvium in situ, \% & 0.140 & 0.080 \\
\hline & b) eroded sands, t/t & $1.4 \cdot 10-3$ & $8 \cdot 10-4$ \\
\hline & c) gross pressing on the urban ecosystem, t/year & 0.286 & 3.926 \\
\hline & d) pressing for 1996-2011 period, t & 4.300 & 58.900 \\
\hline \multirow{4}{*}{ Mo } & a) sands of technogenic eluvium in situ, \% & 0.015 & 0.020 \\
\hline & b) eroded sands, t/t & $1.5 \cdot 10-4$ & $2 \cdot 10-4$ \\
\hline & c) gross pressing on the urban ecosystem, t/year & 0.031 & 0.981 \\
\hline & d) pressing for 1996-2011 period, t & 0.500 & 14.700 \\
\hline
\end{tabular}


(Kasimov, 2013; Chalov et al., 2015). For these elements, the erosion contamination of the urban area and water bodies is calculated (Table 4).

As established by soil-geochemical studies (Kulikov et al., 2012), the cadmium content in the techno-eluvium of both sites was 0.001 $\%$, or $10 \mathrm{~g} / \mathrm{t}$. The small content of cadmium is explained by its relative scarcity and diffusion. Clark cadmium in the earth's crust is $0.13 \mathrm{mg} /$ kg (Vinogradov, 1962).

It is conventionally accepted that in the sediment yield the cadmium content remains the same as in the sands of technoeluvium. Under these assumptions the amount of cadmium in the urban district of Zakamensk from the area of the first site is 0.002 tons per year. From the time of the closure of the mining industry (1998) to the city it decreased to 0.03 tons with erosive runoff. Liquid and solid flows from the second site fall into the watercourse. Therefore, the cadmium contamination of the hydroecosystem from the side of the second site is an order of magnitude higher. Other metals in the sands of techno-eluvium are contained in much larger quantities. So, mercury after the termination of industrial work in the hydroecosystem was in the amount of 3.7 and 155 tons from the first and second sites respectively. Other metals in the pollution of the water system in absolute terms participate to a lesser extent.

\section{Soil drifting}

Another type of desertification in an urbanized area is soil drifting. The critical wind speed is different for particles of different diameters. This explains the sorting of mineral particles along the diameter. Sorting of particles leads to the formation of sand deserts in one case, and clay soils, as well as loess deposits in the surrounding desert territories, in the other. Usually, particles of less than 0.01 and more than $1 \mathrm{~mm}$ remain in place, and coarse particles weighing 0.01-0.05 $\mathrm{mm}$ are carried out over long distances and settle in the form of loess. According to Dolgilevich M.I. (1978), the range of transport of finely dispersed material in dust storms reaches $4000 \mathrm{~km}$. It is as a result of this sorting that loess formed on the periphery of the deserts. It can be rightly argued that the loess plateau and the fertile heylutu soils formed over more than 4000 years of cultivation are due to aeolian material from the Central Asian steppes. The similarity of the material of dust storms of Central Asia, China and Primorye by chemical composition is established (Tolchelnikov, 1990). It is important in the future to show the commonality of the sands of Central Asia and the floodland loess of the Yellow River on microelement composition and the presence of rare elements. According to NASA materials it is established that every year 56 million tons of dust reaches North America from the Central Asian region. Particularly active dust flies in spring in connection with the activation of cyclones and strong western winds, prevailing in the middle latitudes.

From the central and western parts of the Sahara, dust storms penetrate the airspace over the Atlantic Ocean. Taken samples show that dust can spread to South and Central America. For many Asian countries, including Korea, the forecast for the maintenance of Yellow Dust (Yellow Sand, Asian Dust) in the spring with the development of the so-called yellow dust storms becomes actual. To prevent dust storms that disrupt the work of many electronic tools in Mongolia, in the Gobi Desert, the Green Belts program is organized with the help of the international community and research on phytomeliorative sand fixation is beginning.

In the modern era, the problem of forecasting dust storms becomes more urgent. The development of recognition techniques and the conduct of their space monitoring have been carried out since the late 90s. The deciphering of dust storms and evaluation of their main characteristics are carried out with the help of a special Normalized Differential Dust Index (NDDI), which was implemented by Chinese scientists in the study of dust storms in Northern China and Mongolia according to MODIS data (Qu et al., 2006).

Deflationary potential of a wind (DPW) is calculated by the following formula (Pushkarev, 1984):

$$
r_{i}=0.001 \cdot V_{i}^{3} \cdot f_{i}
$$

where $V^{\beta}$ is the wind speed in the speed group $i, f_{i}$ - duration of the wind in percent of the total period in the direction of $j$ and with the group of 
velocities $i$. The calculation of DPW is carried out for each month as a sum for each direction from eight rhumbs.

When predicting the deflation of soils, it is assumed that the kinetic energy of the wind is directly proportional to the cube of its velocity and inversely proportional to the moisture content of the soils. The deflationary work of the wind, having, for example, a speed of $4 \mathrm{~m} / \mathrm{s}$, will exceed the work of a wind having a speed of 2 $\mathrm{m} / \mathrm{s}$, not two but eight times.

Climate index of soil drifting (Chepil et al., 1963):

$C=10^{2} \cdot V^{3} /(H / T+10)^{2}$

where $V, H, T$ - the average annual values of wind speed, precipitation, air temperature, respectively. The cube of wind speed is in the numerator, the square of humidity is in the denominator.

The climatic factor of soil drifting can also be determined by expression:

$$
C=34.486 \cdot 10^{2} \cdot V^{3}(P-E)^{2}
$$

where $P$ - precipitation and $E$ - evaporation.

With an annual erosive wind potential of 50-100, an average of 2-5 dust storms occur annually in the region (Bazhenova et al., 1997; Tyumentseva, 2013). For sands of technoeluvium, antideflation resistance is minimal and equal to 15 . The probability of soil deflation is estimated by score 4 or high. Aeolian accumulation reaches $10 \mathrm{t} / \mathrm{ha} /$ year.

During the soil drifting with contaminated sand the same elements are found in the city and in

Table 5. Deflation pollution of the territory of Zakamensk by heavy metals

\begin{tabular}{|c|c|c|c|}
\hline $\begin{array}{l}\text { Element - } \\
\text { Pollutant }\end{array}$ & Concentration & Site 1 & Site 2 \\
\hline \multirow{3}{*}{$\mathrm{Cd}$} & a) eroded sands, t/t & $1 \cdot 10^{-5}$ & $1 \cdot 10^{-5}$ \\
\hline & b) gross pressing on the urban ecosystem, t/year & $3.04 \cdot 10^{-3}$ & $17.04 \cdot 10^{-3}$ \\
\hline & c) pressing for 1996-2011 period, t & 0.05 & 0,24 \\
\hline \multirow{3}{*}{$\mathrm{Pb}$} & a) eroded sands, t/t & $1.2 \cdot 10^{-3}$ & $2.1 \cdot 10^{-3}$ \\
\hline & b) gross pressing on the urban ecosystem, t/year & 0.37 & 3.58 \\
\hline & c) pressing for 1996-2011 period, t & 5.60 & 53.70 \\
\hline \multirow{3}{*}{$\mathrm{Zn}$} & aeroded sands, $t / t$ & $8 \cdot 10^{-4}$ & $1 \cdot 10^{-3}$ \\
\hline & b) gross pressing on the urban ecosystem, t/year & 0.24 & 1.70 \\
\hline & c) pressing for 1996-2011 period, t & 3.60 & 25.50 \\
\hline \multirow{3}{*}{$\mathrm{Cu}$} & a) eroded sands, t/t & $4 \cdot 10^{-4}$ & $2 \cdot 10^{-4}$ \\
\hline & b) gross pressing on the urban ecosystem, t/year & 0.12 & 0.34 \\
\hline & c) pressing for $1996-2011$ period, $t$ & 1.80 & 5.10 \\
\hline \multirow{3}{*}{ W } & a) eroded sands, t/t & $1.4 \cdot 10^{-3}$ & $8 \cdot 10^{-4}$ \\
\hline & b) gross pressing on the urban ecosystem, t/year & 0.43 & 1.36 \\
\hline & c) pressing for 1996-2011 period, t & 6.50 & 20.40 \\
\hline \multirow{3}{*}{ Mo } & a) eroded sands, t/t & $1.5 \cdot 10^{-4}$ & $2 \cdot 10^{-4}$ \\
\hline & b) gross pressing on the urban ecosystem, t/year & 0.05 & 0.34 \\
\hline & c) pressing for 1996-2011 period, t & 0.80 & 5.10 \\
\hline
\end{tabular}


the hydroecosystem, which are contained in the techno-eluvium (Table 5). Since the closure of the mining enterprise (1998), deflation tungsten contamination has reached 6.5 tons in the first site. The hydroecosystem received 20 tons of tungsten from this site. Also great are the aerial incomes of lead, copper, etc.

\section{CONCLUSIONS}

The retrospective analysis of the available materials on the assessment of the environmental condition in Zakamensk, personal observations and especially the analysis of the latest research result on remote and ground-based sensing of the state of the day surface revealed the following:

1. The main source of the environment pollution are tailings and mine water.

2. The main factor of pollution is toxic substances, primarily, heavy metals, inheriting high concentrations from ore rock, and currently deposited in the tailings material, as well as pollutants contained in mine waters.

3. The main processes contributing to the expansion of the pollution area are: a) wind separation covering a vast territory; b) plane washout and linear erosion, especially intense during spring and summer floods; c) lateral underground filtration and outlets of the mine water; $d$ ) alluvial demolition of the river Modonkul redeposited material; e) anthropogenic dispersion, consisting in the occasional use of sand for dumping roads, playgrounds, in construction, etc.

The scheme for grouping the adverse effects of the DTMP waste by source, factor and process has been developed. The territory of Zakamensk is differentiated into areas of ecological disaster and an extreme ecological situation. The whole other territory of the town refers to the zone of satisfactory situation. One special transit area associated with the pollution of the bottom sediments of the river Modonkul was identified. It is determined by the coefficient of the bottom accumulation of heavy metals and refers to the zone of ecological disaster.

Desertification processes in the territory of Zakamensk (urban desertification ) manifest themselves in the form of sheet and linear erosion and redeposition (erosion), soil drifting and redeposition (contamination) of sands contaminated with heavy metals, the legacy of the mining activity of the now closed Dzhidinsky tungsten-molybdenum plant.

The long-term dynamics of such an important indicator as the rainfall erosion index occurs with a positive trend -2.5 units/10 years, i.e. the probability of erosion-hazardous rains in the region is increasing.

With the use of modern calculation methods, it has been established that the city limits with water-erosion flows to 204 t / ha of contaminated sands each year, and only after the closure of the plant in 1996, priority pollutants such as lead 3.7 t, tungsten $-4.3 \mathrm{t}$.

Active wind activity led to the deposition of even more metals in the city. Urban ecosystems of Zakamensk are under deflation metal pressing (for lead is equal $5.6 \mathrm{t}$, and tungsten $-6.5 \mathrm{t}$ ).

Qualitative characteristics of the surface waters of the river Modonkul belong to the very dirty class $(\mathrm{VI})$, while the river remains the most polluted water object in the republic as a result of the discharge of mine waters of the frozen DTMP.

Wastewater from tunnels is characterized by an increased content of chromium, zinc, cadmium, iron and other metals.

Pollution by heavy metals has a negative impact on the health of the residents of Zakamensk. Air pollution caused the risk of increasing such diseases as cardiovascular, lung cancer, chronic and acute respiratory, including asthma among the citizens (Kulikov et al., 2012). Therefore, urgent reclamation and remediation of contaminated sands of technoeluvium, 
rehabilitation of the territory of Zakamensk of the Republic of Buryatia is necessary.

The ecological situation in Zakamensk and in its adjacent territory is qualified as an ecological disaster, and for the general morbidity (according to the population's consultation in medical institutions) - as a crisis.

\section{ACKNOWLEDGEMENTS}

This work was carried out within the framework of a state assignment of the Baikal Institute of Nature Management of Siberian Branch of Russian Academy of Sciences (project No. AAAA-A17-117021310251-4) and partially supported by the Russian Foundation for Basic Research under research project No. 19-55-53026.

\section{REFERENCES}

Bazhenova O.I., Lyubtsova E.M., Ryzhov Yu.V., Makarov S.A. (1997). Spatio-temporal analysis of the dynamics of erosion processes in the south of Eastern Siberia. Novosibirsk: Nauka. 203 p. (in Russian with English summary)

Belotserkovskiy M.Yu. and Topunov M.V. (1996). The cost of anti-erosion measures to preserve soil fertility with the existing agricultural use of arable land. In: R.S. Chalov, ed., Erosion and channel processes. Issue 2. Materials of coordination meetings of universities in 1991-1995, Moscow: MSU, pp. 48-54. (in Russian with English summary)

Chalov S., Jarsjö J., Kasimov N. Romanchenko A., Pietroń J., Thorslund J., Promakhova E. (2015). Spatio-temporal variation of sediment transport in the Selenga River Basin, Mongolia and Russia. Environmental Earth Sciences, 73, pp. 663-680. doi: 10.1007/s12665-014-3106-z

Chalov S., Kasimov N., Lychagin M., Alexeevsky N., Belozerova E., Theuring P., Shinkareva G., Romanchenko A., Garmaev E. (2013). Water resources assessment of the Selenga-Baikal river system. Geoöko, 34, pp. 77-102.

Chepil W.S., Siddoway F.N., Armbrust D.V. (1963). Climatic index of wind erosion conditions in the Great Plains. Soil Science Society of America Journal, 27, pp. 449-452.

Dolgilevich M.I. (1978). Dust storms and agroforestry meliorative events. Moscow: Kolos. 159 p. (in Russian with English summary)

Environmental Atlas-monograph "Selenga-Baikal" (2019). Edited by N. Kasimov. M.: Faculty of Geography, MSU. 208 p. Available at: https://www.researchgate.net/ publication/335567904_Environmental_Atlas-monograph_Selenga-Baikal

GOST 25100-95. Soils. Classification (2001). Moscow. 23 p. (in Russian)

Implementation of environmental measures related to the shutdown of the Dzhidinsky tungsten-molybdenum plant in Zakamensk: assessment of the environmental situation in the adjacent area of the former DTMP: economic agreement report (interim) (2007). In: A.l. Kulikov, ed., Ulan-Ude: Buryat State Academy of Agriculture. (in Russian)

Ivanov A.D. (1971). Some results of studying of aeolian sands and soil deflation in Transbaikalia. Wind erosion and control measures. Bulletin of Institute of natural sciences of Buryat subbranch of Siberian branch of USSR Academy of sciences, 9, pp. 131-137. (in Russian with English summary) 
Karthe, D., Kasimov, N., Chalov, S., Shinkareva, G., Malsy, M., Menzel, L., Theuring, P., Hartwig, M., Schweitzer, C., Hofmann, J., Priess, J., Lychagin, M. (2014) Integrating Multi-Scale Data for the Assessment of Water Availability and Quality in the Kharaa - Orkhon - Selenga River System. Geography, Environment, Sustainability, 3(7) pp. 65-86. doi: 10.24057/2071-93882014-7-3-40-49

Karthe D., Chalov S., Moreido V., Pashkina M., Romanchenko A., Batbayar G., Kalugin A., Westphal K., Malsy M., Flörke M. (2017). Assessment of runoff, water and sediment quality in the Selenga River basin aided by a web-based geoservice. Water Resources, 44 (3), pp. 399-416. doi: 10.1134/S0097807817030113

Kasimov N., Kosheleva N., Gunin P., Korlyakov I., Sorokina O., Timofeev I. (2016). State of the environment of urban and mining areas in the Selenga Transboundary River Basin (Mongolia Russia). Environmental Earth Sciences, 75 (1283), pp. 1-20. doi: 10.1007/s12665016-6088-1

Kasimov N.S. (2013). Landscape Ecogeochemistry. Moscow: publisher Filimonov M.V. 208 p. (in Russian with English summary)

Khamnaeva G.G., Kulikov A.I., Tsydypov, B.Z. (2013). Current ecological state of the Zakamensk city environment and its adjacent territory. Bulletin of Buryat State Academy of Agriculture, 3(32), pp. 79-85. (in Russian with English summary)

Kovalev S.N. (2009). Development of gully in urban areas. Ph.D. author's abstract. Moscow. 25 p. (in Russian)

Kulikov A.I., Mangataev A.Ts., Kulikov M.A., Hamnaeva G.G., Plyusnin A.M. (2012). Ecological zoning and statistical parameters of ecologically dangerous zones of Zakamensk (the Republic of Buryatia). ESSUTM bulletin, 3 (38). pp. 221-227. (in Russian with English summary)

Kuznetsov M.S. and Glazunov G.P. (2004). Soil erosion and protection. Moscow: MSU. 352 p. (in Russian with English summary)

Larionov G.A. (1993). Soil erosion and deflation: basic patterns and quantitative assessments. Moscow: MSU. 198 p. (in Russian with English summary)

Litvin L.F. and Kiryukhina Z.P. (2002). Erosion dangerous lands and spatio-temporal patterns of soil erosion. Natural-anthropogenic processes and environmental risk, Moscow: Gorodets. pp. 196-202. (in Russian with English summary)

Litvin L.F. and Kiryukhina Z.P. (2004). Soil-erosion migration of nutrients and pollution of surface waters. Soil erosion and channel processes, 14, pp. 45-64. (in Russian with English summary)

Osintseva N.V. (2001). Physico-geographical factors of development of gully erosion of urban lands. Ph.D. author's abstract. Tomsk. (in Russian)

Pushkarev M.F. (1984) Soil Erosion (Translation from English); Kolos: Moscow, Russia. 415 p. (in Russian)

Qu John, Hao Xianjun, Kafatos Menas, Wang Lingli (2006). Asian Dust Storm Monitoring Combining Terra and Aqua MODIS SRB Measurement. IEEE Geoscience and Rernote Sensing Letters, 3(4), pp. 284-486. 
Timofeev I., Kosheleva N., Kasimov N. (2018). Contamination of soils by potentially toxic elements in the impact zone of tungsten-molybdenum ore mine in the Baikal region: A survey and risk assessment. Science of the Total Environment, 642, pp. 63-76. doi: 10.1016/j. scitotenv.2018.06.042

Tolchelnikov Yu.S. (1990). Soil erosion and deflation. Ways to control. Moscow: Agropromizdat. 158 p. (in Russian with English summary)

Tulokhonov A.K., Tsydypov B.Z., Sodnomov B.V., Gurzhapov B.O., Ayurzhanaev A.A., Batotsyrenov E.A., Togmidon V.V., Ayusheev Ch.Yu., Zharnikova M.A., Alymbaeva Zh.B., Garmaev E.Zh. (2018). Assessment of the linear erosion development through the example of a gully in the Selenga Middle Mountains. Izvestiya vuzov «Geodeziya i aerofotosyemka». Izvestia vuzov «Geodesy and Aerophotosurveying», 62 (3): 327-336. (in Russian with English summary)

Tyumentseva E.M. (2013). The use of statistical methods in the study of aeolian processes. Bulletin of the Department of Geography of ESSAE, 1-2 (7), pp. 38-46. (in Russian with English summary)

Vinogradov A.P. (1962). The average content of chemical elements in the main types of igneous rocks of the earth's crust. Geochemistry, 7, pp. 555-571. (in Russian with English summary)

Wischmeier W.H. (1959). A rainfall erosion index for universal soil-loss equation. Soil Science Society of America Journal, 23, pp. 246-249. doi: 10.2136/sssaj1959.03615995002300030027x

Wischmeier W.H. and Smith D.D. (1958). Rainfall energy and its relationship to soil loss. Eos, Transactions American Geophysical Union, 39, pp. 285-291. doi: 10.1029/TR039i002p00285

Wischmeier W.H. and Smith D.D. (1978). Predicting rainfall erosion losses. USDA Agr. Handbook 537, Washington. 65 p. 